\title{
(웅
}

KIRJA-ARVIO

\author{
Roni Grén
}

\section{Esihistorian moderni luomus}

Esihistoria, modernismi, taide, arkeologia, taidehistoria, antropologia

FT, dos. Roni Grén, taidehistoria, Turun yliopisto, rkgren@utu.fi

Rémi Labrusse, Prehistoire: 1'envers du temps. Paris: Éditions Hazan, 2019. 240 sivua. Cécile Debray, Rémi Labrusse \& Maria Stavrinaki, dir. Préhistoire: une énigme moderne, Paris: Éditions du Centre Pompidou, 2019. 304 sivua.

Pariisin Pompidou-keskuksessa järjestettiin 8.5.-16.9.2019 näyttely "Préhistoire. Une énigme moderne", joka esitteli esihistoriallisen aineiston ja modernin kuvataiteellisen avantgarden nivoutumista yhteen. Näyttelyn tiimoilta julkaistiin myös samanniminen näyttelyluettelo ja siihen sidoksissa oleva Paris Nanterre -yliopistossa (Paris X) nykytaiteen historian professorina toimivan Rémi Labrussen monografia Prébistoire: L'envers du temps. Erityisesti monografia käsittelee ansiokkaasti esihistorian käsitettä, sen yhteistä historiaa modernin taiteen ja taidekäsityksen kanssa sekä tämän suhteen erilaisia oireita. Arviossani keskityn monografiaan, mutta kirjat ovat tarkoitetut toisiaan täydentäviksi, sillä eri kustantajista huolimatta jopa niiden taittoratkaisut on luotu yhtenäisiksi. Näyttelyluettelo on fragmentaarinen kokonaisuus lyhyitä näyttelytekstejä ja osittain samojakin teoksia, joista myös monografiassa puhutaan, mikä tuo syvyyttä Labrussen teoksessa luotuihin argumentteihin juuri hajanaisuudellaan ja tapauskertomuksillaan. 


\section{Esihistorian ylihistoriallisuus}

Labrussen kirjan polttopisteessä on nimenomaan ranskalainen esihistoriaa koskeva keskustelu ja sen luonne sekä Ranskan maaperältä löytyneet esihistorialliset kohteet, vaikka niiden kautta puhutaankin esihistoriasta ja sen tutkimuksesta yleensä. Tämä on pitkälti ymmärrettävää, koska ranskalainen keskustelu on hallinnut sekä esihistoriallisten esineiden että luolamaalausten tulkintaa meidän päiviimme saakka ja etenkin sunnilleen 1850-luvulta 1900-luvun puoliväliin, jota aikaväliä teos enimmiltään koskee.

Alkupisteen käsittelyilleen Labrusse kuitenkin ottaa varhaisemmalta kaudelta, Jean-Jacques Rousseaulta ja muun muassa hänenkin ajatustensa kehityksestä saksalaisen romantiikan, erityisesti Friedrich Schellingin, edustamissa näkemyksissä. Esihistoriassa (Vorzeit tai vorgeschichtliche Zeit) kyse on ennemminkin filosofisesta tukipilarista, jolla Schellingillä "ajan perusta", tai Rousseaun tapauksessa "yhteiskuntasopimuksen" ihanteellinen alkutila, voidaan avata lukijalle ja tehdä se ymmärrettäväksi. Näin esihistoriallinen aika näyttäytyy filosofisen projektion tilana, johon jotakin ihmisluonteeseen kuuluvaa, pysyväksi käsitettyä ja nykyhetkessä havaittavaa projisoidaan muuten mittasuhteiltaan käsittämättömäksi jäärän kohteeseen.
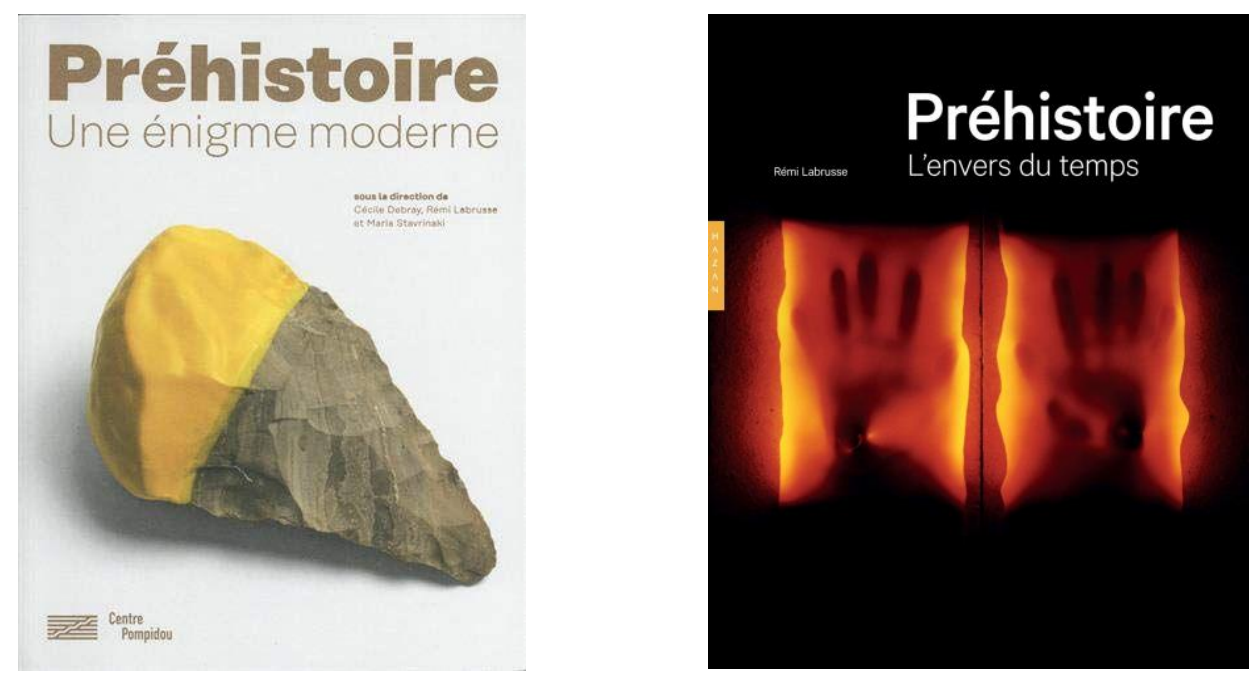

Labrusse jakaa lapsenkengissään läpi 1800-luvun olleen esihistorian tutkimuksen varsin pätevältä tuntuvalla tavalla kolmeen vaiheeseen. Ensimmäistä määrää esihistorian käsittäminen antediluviaanisen, Raamatun suurta tulvaa edeltävän ajan maailmana, johon aletaan luoda luonnontieteellisiä katseita erityisesti fossiileja koskeneen lisääntyneen ymmärryksen kautta yhä enemmän ja enemmän muun muassa 1800-luvun alkupuolella julkaistujen Georges Cuvierin ja Charles Lyellin tekemien tutkimusten kautta. Toinen vaihe määrittyy siitä hetkestä lähtien, kun tutkijoiden on myönnettävä myös ibmisen esibistorian ulottuvan paljon pidemmälle kuin mille tulkinta raamatullisessa valossa oli antanut sijaa ja jolloin ihmisen esihistoriallista kulttuuria koskeva todistusaineisto on kasvanut riittävän suureksi yhdessä evoluutioteorian kehittymisen kanssa: ratkaiseva vuosi on 1859, jolloin Jacques Boucher de Perthes kirjoittaa tekemiensä löytöjen pohjalta teoksen De l'Homme antédiluvien et de ses auvres ja Charles Darwinin Lajien synty julkaistaan.

Näiden kahden esihistoriallisen tutkimuksen vaiheen välisen sïrtymän kautta Labrussen kirjan alkupuoli avaa sen vaikutuksia niin teoreettisesti kuin aikakauden kuvakulttuurinkin osalta tuoden esihistoriaan liitetyn ylihistoriallisen moraalisen projektion päivänvaloon. Näitä kuvaa ensimmäisen vaiheen osalta mitä parhaiten Honoré de Balzacilta monografian yhden osan otsakkeeksi lainattu ilmaus "Apoca- 
lypse rétrograde", menneisyydestä mallinsa ottanut visio maailmanlopusta (minkä seurauksia voidaan jäljittää 1800-luvun ihmishahmoista tyhjennetyistä maisemista esihistoriaa kuvaaviin b-elokuviin), tai toisen vaiheen osalta niin ikään otsikkoon päätynyt "L’immémorial", joka negatiivisuutensa kautta toimii sanaleikkinä ikimuistoisen ja muistamattomuuden välillä syntyviin konnotaatioihin.

\section{Työ, taide, vallankumous}

Kolmas vaiheista liittyy monipolviseen historiaan, jonka kautta luolamaalauksista tulee esihistorian näkyvin osa pitkän niiden aitoudesta käydyn polemiikin jälkeen, ja jonka myötä niistä aletaan puhua "esihistoriallisena taiteena": Altamiran maalaukset löydettiin vuonna 1879, mutta konsensus niiden aitoudesta saavutettiin vasta vuonna 1902. Labrusse jäljittää keskustelua aina de Perthes’n töihin asti, ja pohtii työn (ja työkalujen) asettamista 1860-luvun alussa esihistoriallisen ihmisen kulttuurin malliksi. Kieltämällä esihistoriallisen ihmisen työtä laajemmat kulttuuriset pyrkimykset perinteinen kehitystarina ihmislajin kehityksestä saatiin vielä tuolloin pidettyä yllä, mutta Labrusse etenee myös sen pohjalta miettimään, miten ajatus työstä esihistoriallisen kulttuurin mallina saattoi muokata aikakauden taidekäsitystä ja toimia sen kanssa yhdessä (esim. Arts and Crafts ja taideteollisuuden synty).

Luolamaalausten tultua hyväksytyksi taiteena ne taas Labrussen mukaan jopa pimensivät muun esihistoriatutkimuksen ja määrittelivät niin populaarikulttuurin kuin monien tieteentekijöidenkin lähestymiskulman esihistoriaan. Näin on painotetusti nimenomaan Ranskassa, jossa Euroopan merkittävimmät luolamaalauskohteet sijaitsevat, mutta ranskalaisen keskustelun tutkimuskenttää pitkään johtaessa voi ajatusta pitää pätevänä laajemminkin. Juuri tässä kohden myös näyttelyluettelo tulee massiivisen kuva-aineiston kera avuksi ja näyttää miten nimenomaan sotienvälisen avantgardistisen taidekentän kautta ja sen laitamilla ilmestyneiden julkaisujen (esim. Cahiers d'art ja Documents) sekä muutaman suuremman näyttelyprojektin (erit. MoMAn vuoden 1937 "Modern Art 5000 Years Ago" ja Lontoon Institute of Contemporary Artsin vuoden 1948 "40 000 Years of Modern Art") myötä luolamaalaukset rinnastetaan aikakauden uusimpaan taiteeseen ja ylihistoriallinen näkökulma saa osansa. Tässä ranskalainen konteksti auttaa jälleen: ranskalainen etnologia ja antropologia kehittyivät ylipäätään muun muassa Marcel Maussin, Michel Leirisin ja Georges-Henri Rivièren kautta läheisissä suhteissa pariisilaiseen avantgarde- ja museokenttään.

Tähän liittyy myös kirjan yksi keskeisistä historiografisista huomioista. Labrussen mukaan avantgarde-taiteenkin historiaan sujuvasti sijoittuva ajatus vallankumouksista, joka toki on ollut osa modernia retoriikkaa alusta asti, ujutettiin nopeasti osaksi myös esihistoriaa koskevaa puhetta, joka loi ylihistoriallisuuden rinnalle modernin maailman historialliseksi peiliksi ajatuksen äkkinäisistä murroksista. Näillä selitettiin niin ihmislajin kuin taiteenkin syntyä ja yhä nykyään kielenkäytössä viljeltävää "neoliittistä vallankumousta", vaikka tosiasiassa kaikki ne on samaan aikaan ymmärretty oikeammin asteittaisina prosesseina, jotka ovat ottaneet kehittyäkseen vuosituhansia. Neoliittisen vallankumouksen hahmoa Labrusse tavoittelee vielä kirjansa viimeisessä käsittelyosassa ja miettii siihen luodun katseen ulottuvuuksia yhteyksissä poliittisiin mieltymyksiin ja sitä, miten sen käsittäminen toivottavaksi tai ei-toivottavaksi saattoi johtaa hyvinkin erilaisin "reaktionäärisiin", "vallankumouksellisiin", "progressistisiin" tai "nihilistisiin" ajattelumalleihin. 
Kaiken kaikkiaan Labrussen teos on erittäin informatiivinen ja hän käyttää hyvin laajaa lähdemateriaalia, jota vastaavalla tavalla ei ole aiemmin tuotu yhteen. Hermeneuttisen projektion juuret olisi toki ollut mahdollista paikantaa laajemmin pidemmällekin, esimerkiksi antiikkiin (kulta-aika) tai kirjan aikarajausta varhaisempaan kristilliseen kulttuuriin (paratiisi), mutta niin Labrusse ei kirjassaan ryhdy tekemään. Ylipäätäänkin on todettava, että jos kirjojen sokeaa pistettä jostakin on syytä hakea, löytyy se uskonnon kysymysten käsittelystä, joille ei oikeastaan anneta tilaa kuin luonnontieteelliseen murrokseen liittyvän vaiheen kautta ikään kuin toissijaisesti, sekä 1870-1880-lukujen esihistorian tutkimuksen auktoriteetin Gabriel de Mortillet'n hyvin tunnetun antiklerikalismin, jonka voi nähdä ohjanneen vahvasti myös alan tutkimuksen ottamia suuntia, kohdalla. Uskonnollisen tulkinnan merkitys oli kuitenkin hyvin tärkeä myös luolamaalauksia koskeneessa tulkintatraditiossa erityisesti 1900-luvun alkupuolella.

Toinen suuri puute koskee esihistoriallisen kulttuurin ja modernismiin tiukasti linkittyvien primitivististen virtausten suhdetta. Kuten Labrussekin huomioi, esihistoriallinen kuvasto erotettiin selkeästi modernia maailmaa asuttaneiden primitiivien taiteesta. Perinteisiä selitysmalleja tälle ovat olleet etenkin luolamaalausten eläinkuvien naturalismi ja toisaalta kolonialistinen historia, joka halusi perustaa luolamaalauslöydöt osana eurooppalaista kulttuuriperimää, kun taas primitiivinen taide avautui kolonialismin kehyksessä valloitetun toiseuden todisteiksi. Myös Labrusse käsittelee esihistoriallisten esineiden ja kohteiden nationalistista appropriaatiota, mutta primitiivin käsite itsessään olisi kaivannut, etenkin kun taiteiden alueesta puhutaan, laajemman problematisoinnin. Suhde ei kuitenkaan ole niin selvästi kaksijakoinen, että primitivismit voisi helposti jättää jakolinjan alapuolelle vailla yhteyttä esihistorian käsitteeseen. Usein myös esihistoriasta kirjoittaneet merkittävät tutkijat tai siitä hullaantuneet taiteilijat olivat jossain vaiheessa uraansa tekemisissä myös aikakauden primitivismin kanssa. Lisäksi primitivismillä on aihepiirin kanssa yhteinen käsitteellinen juuri 1700-luvun rousseaulaisissa keskusteluissa, vaikka esibistoria käsitteenä ei silloin vielä ollutkaan kehittynyt.

Näistä puutteista huolimatta Labrussen teos on merkittävä kokonaisuus ja metodisestikin kiinnostava yhdistelmä erilaisia näkökulmia. Kirjan loppu on tässä suhteessa mietityttävä ja oivaltava. Päätösluvussa hän palaa vielä teoksen suurimpaan teemaan, esihistorian käsitettä alusta asti määrittäneeseen epähistoriallisuuden ja historiallisuuden yhteispeliin, jonka hän tuo esiin jopa hyvin henkilökohtaisia painotuksia omaavan fenomenologisen kuvauksen kautta, missä hän kuvaa ajattelunsa toimintaa luolamaalauskohteiden edessä. Kuvaus jää vaivaavalla tavalla muistuttamaan kysymyksestä, miten fantasiat epä- ja ylihistoriallisuudesta johtavat tulkintaa historiasta ja päinvastoin. 